\title{
Highly Enantioselective Transfer Hydrogenation of Prochiral Ketones Using Ru(II)-Chitosan Catalyst in Aqueous Media
}

\author{
György Szőllősi ${ }^{*[a, b]}$ and Vanessza Judit Kolcsár ${ }^{[c]}$
}

\begin{abstract}
Unprecedentedly high enantioselectivities are obtained in the transfer hydrogenation of prochiral ketones catalyzed by a Ru complex formed in situ with chitosan chiral ligand. This biocompatible, biodegradable chiral polymer obtained from the natural chitin afforded good, up to $86 \%$ enantioselectivities, in the aqueous-phase transfer hydrogenation of acetophenone derivatives using HCOONa as hydrogen donor. Cyclic ketones were transformed in even higher, over $90 \%$, enantioselectivities, whereas further increase, up to $97 \%$, was obtained in the transfer hydrogenations of heterocyclic ketones. The chiral catalyst precursor prepared ex situ was examined by scanning
\end{abstract}

electron microscopy, FT-mid- and -far-IR spectroscopy. The structure of the in situ formed catalyst was investigated by ${ }^{1} \mathrm{H}$ NMR spectroscopy and using various chitosan derivatives. It was shown that a Ru pre-catalyst is formed by coordination of the biopolymer to the metal by amino groups. This precursor is transformed in water insoluble Ru-hydride complex following hydrogen donor addition. The practical value of the developed method was verified by preparing over twenty chiral alcohols in good yields and optical purities. The catalyst was applied for obtaining optically pure chiral alcohols at gram scale following a single crystallization.

\section{Introduction}

During the last few decades the increased demand of optically pure fine chemicals accelerated the development of asymmetric catalytic procedures. ${ }^{[1]}$ Among the most convenient stereoselective reactions are the enantioselective hydrogenations of prochiral compounds. A huge variety of metal complexes and heterogeneous chiral catalysts have been developed and successfully applied in asymmetric hydrogenations of diverse unsaturated chemicals. ${ }^{[2]}$ The operational simplicity brought by the use of organic or inorganic hydrogen donors instead of $\mathrm{H}_{2}$ gas promoted studies aimed at designing chiral catalysts efficient in enantioselective transfer hydrogenations (ETH) of various prochiral compounds. ${ }^{[3]}$ In their pioneering work Noyori, Ikariya and co-workers developed efficient ruthenium complexes using sulfonamides derived from optically pure diamines for these purposes. ${ }^{[4]}$ According to recent trends in the fine

\section{[a] Dr. G. Szöllősi}

MTA-SZTE Stereochemistry Research Group

University of Szeged

Dóm tér 8

Szeged 6720 (Hungary)

[b] Dr. G. Szöllösi

University of Szeged

Interdisciplinary Excellence Centre

Institute of Pharmaceutical Chemistry

Eötvös u. 6

Szeged 6720 (Hungary).

E-mail: szollosi@chem.u-szeged.hu

[c] V. J. Kolcsár

Department of Organic Chemistry

University of Szeged

Dóm tér 8

Szeged 6720 (Hungary)

Supporting information for this article is available on the WWW under https://doi.org/10.1002/cctc.201801602 chemical industry efforts are devoted to replace the synthetic, expensive ligands with natural, renewable chiral compounds.

Chitosan (CS, Figure 1) is obtained by deacetylation from chitin (CT), ${ }^{[5]}$ which is the second most abundant chiral natural polymer available in large quantities from food industry wastes. This biocompatible and biodegradable polymer has multiple applications in food, pharmaceutical and medicinal industry, in separation and purification processes, water treatment, cosmetics, and as biosensors. ${ }^{[6]}$ It is also a proper candidate for developing cheap and stereoselective catalysts. CS has been used for the preparation of chiral organocatalysts either by coupling with catalytically active molecules or just using the natural chirality of this biopolymer. ${ }^{[7]}$ Its ability to chelate metal cations was exploited to prepare catalytically active metal complexes and supported metal particles. ${ }^{[8]}$ These materials were also applied as asymmetric catalysts employing the chirality of the CS. ${ }^{[9]}$ Among these applications the enantioselective hydrogenations and transfer hydrogenations were the most studied. Early attempts on using such catalysts in enantioselective hydrogenations of prochiral ketones gave uncertain, irreproducible results, ${ }^{[10]}$ whereas moderate enantioselectivities were reached in ETH even following chemical modification of chitosan used as chiral ligand. ${ }^{[11]}$ At best $78 \%$

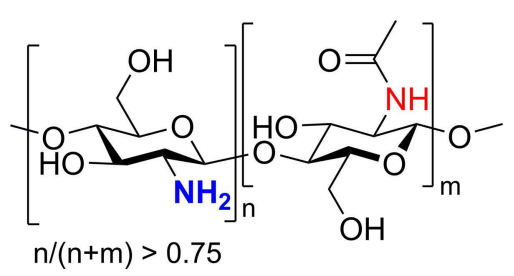

Figure 1. Structure of chitosan (CS). 
enantiomeric excess (ee) was obtained in the transfer hydrogenation of aromatic ketones using the Ru complex of 6-Opivalate derivative of CS. $^{[12]}$

In the present study our goal was to develop a simple, environmentally benign method for the ETH of prochiral ketones in aqueous media using unmodified CS from commercial source as degradable, renewable, chiral ligand.

\section{Results and Discussion}

We commenced our experiments with the transfer hydrogenations of acetophenone ( $1 \mathrm{a})$ and its two substituted derivatives ( 1 b and 1 c, Scheme 1 ) using in situ formed chiral Ru complex from a high molecular weight chitosan (CS1, see Experimental section) and $\left[\mathrm{Ru}(p-\mathrm{cym}) \mathrm{Cl}_{2}\right]_{2}$ ( $p$-cym: para-cymene) (see Table 1). Initially sodium formate was applied as hydrogen donor (H-donor). The reaction of $\mathbf{1} \mathbf{a}$ in water resulted in similar ee as described previously (entries $1-3$ ). ${ }^{[12]}$ However, using 20 vol \% isopropanol ( $\mathrm{PrOH}$ ) the ee increased up to $78 \%$, reaching the highest value obtained up to now in ETH using CS derived ligand. Even higher ee values were obtained under identical conditions in the ETH of $\mathbf{1} \mathbf{b}$ and $\mathbf{1} \mathbf{c}$ (entries 5, 10), however, the reaction of the latter had to be extended to $70 \mathrm{~h}$ for reaching good conversion (entry 11). By increasing the amount of $\mathrm{PrOH}$ in the mixture the ee slightly decreased (compare entries 1113). Replacement of $i \mathrm{PrOH}$ with other polar, water miscible solvents $(\mathrm{MeOH}, \mathrm{EtOH}$ or $\mathrm{N}, \mathrm{N}$-dimethylformamide (DMF)) decreased both the conversion and the ee (entries 14-16). $\mathrm{HCOONa}$ and $\mathrm{HCOOK}$ were similarly efficient $\mathrm{H}$-donors (entries 5, 6), whereas using $\mathrm{HCOONH}_{4}$ or $\mathrm{HCOOH} / \mathrm{Et}_{3} \mathrm{~N} 5 / 2$ mixture resulted in low conversions (entries 7,9 ). The attempt of using iPrOH as $\mathrm{H}$-donor in the presence of a strong base $(\mathrm{KOH})$ provided moderate conversion and lower ee even at higher reaction temperature (entry 8 ).

Chiral Ru catalyst formed with CS1 ligand was also prepared ex situ in water by slow evaporation of the solvent using the same ratio of ligand/metal precursor as in the transfer hydrogenations (see Experimental section). An orange film-like material was obtained (denoted as Ru-CS1), which was easily cut or broken in pieces (Figure 2). This material provided similar results as the in situ formed catalyst in the reactions of all three compounds (Table 1, entries 4, 5, 10) even after a long-time storage (close to one year).<smiles>[R]c1cc([R])cc(C(C)=O)c1</smiles>

1a: $R^{1}, R^{2}=H$;

1b: $R^{1}=H, R^{2}=C F_{3}$;

1c: $R^{1}, R^{2}=\mathrm{CF}_{3}$

Scheme $\mathbf{1}$. Asymmetric transfer hydrogenation of acetophenones $\mathbf{1} \mathbf{a}, \mathbf{1} \mathbf{b}$ and $1 \mathrm{c}$ using chitosan CS1 as chiral ligand.
Table 1. Investigation of the solvent and $\mathrm{H}$-donor effect on the transfer hydrogenation of $1 \mathrm{a}, \mathbf{1} \mathrm{b}$ and $1 \mathrm{c}$ using chitosan CS1 as ligand. ${ }^{[a]}$

\begin{tabular}{|c|c|c|c|c|c|}
\hline Entry & Ketone & Solvent & $\begin{array}{l}\text { H-donor; amount } \\
\text { [mmol] }\end{array}$ & $\begin{array}{l}\text { Conv } \\
\text { [b] } \\
{[\%]}\end{array}$ & $\begin{array}{l}e e^{[c]} \\
{[\%]}\end{array}$ \\
\hline 1 & $1 \mathrm{a}$ & $\mathrm{H}_{2} \mathrm{O}$ & HCOONa; 0.75 & 66 & 71 \\
\hline 2 & $1 \mathrm{a}$ & $\mathrm{H}_{2} \mathrm{O}$ & HCOONa; 1.25 & 87 & 71 \\
\hline 3 & $1 \mathrm{a}$ & $\mathrm{H}_{2} \mathrm{O}$ & HCOONa; 2.50 & 99 & 70 \\
\hline 4 & $1 \mathrm{a}$ & $\begin{array}{l}\mathrm{H}_{2} \mathrm{O} / \mathrm{iPrOH} \\
4 / 1\end{array}$ & HCOONa; 1.25 & $\begin{array}{l}99 ; \\
92^{[d]}\end{array}$ & $\begin{array}{l}78 \\
77^{[d]}\end{array}$ \\
\hline 5 & $1 \mathrm{~b}$ & $\begin{array}{l}\mathrm{H}_{2} \mathrm{O} / \mathrm{iPrOH} \\
4 / 1\end{array}$ & HCOONa; 1.25 & $\begin{array}{l}99 ; \\
98^{[d]}\end{array}$ & $\begin{array}{l}85 \\
85^{[d]}\end{array}$ \\
\hline 6 & $1 \mathrm{~b}$ & $\begin{array}{l}\mathrm{H}_{2} \mathrm{O} / \mathrm{iPrOH} \\
4 / 1\end{array}$ & HCOOK; 1.25 & $>99$ & 85 \\
\hline 7 & $1 \mathrm{~b}$ & $\begin{array}{l}\mathrm{H}_{2} \mathrm{O} / \mathrm{iPrOH} \\
4 / 1\end{array}$ & $\mathrm{HCOONH}_{4} ; 1.25$ & 3 & 5 \\
\hline 8 & $1 \mathrm{~b}$ & $\begin{array}{l}\mathrm{H}_{2} \mathrm{O} / \mathrm{iPrOH} \\
4 / 1\end{array}$ & $\mathrm{KOH} ; 0.25^{[\mathrm{e}]}$ & 55 & 75 \\
\hline 9 & $1 \mathrm{~b}$ & $\begin{array}{l}\mathrm{H}_{2} \mathrm{O} / \mathrm{iPrOH} \\
4 / 1\end{array}$ & $\begin{array}{l}\mathrm{HCOOH} / \mathrm{EtN}_{3} 5 / 2 ; \\
0.1 \mathrm{~cm}^{3}\end{array}$ & 3 & 4 \\
\hline 10 & $1 \mathrm{c}$ & $\begin{array}{l}\mathrm{H}_{2} \mathrm{O} / \mathrm{iPrOH} \\
4 / 1\end{array}$ & HCOONa; 1.25 & $\begin{array}{l}62 ; \\
63^{[d]}\end{array}$ & $\begin{array}{l}86 ; \\
85^{[d]}\end{array}$ \\
\hline $11^{[\mathrm{ff}}$ & $1 \mathrm{c}$ & $\begin{array}{l}\mathrm{H}_{2} \mathrm{O} / \mathrm{iPrOH} \\
4 / 1\end{array}$ & HCOONa; 1.25 & 90 & 86 \\
\hline $12^{[f]}$ & $1 \mathrm{c}$ & $\begin{array}{l}\mathrm{H}_{2} \mathrm{O} / \mathrm{iPrOH} \\
3 / 2\end{array}$ & HCOONa; 1.25 & 98 & 83 \\
\hline $13^{[f]}$ & $1 \mathrm{c}$ & $\begin{array}{l}\mathrm{H}_{2} \mathrm{O} / \mathrm{iPrOH} \\
2 / 3\end{array}$ & HCOONa; 1.25 & 99 & 83 \\
\hline $14^{[f]}$ & $1 \mathrm{c}$ & $\begin{array}{l}\mathrm{H}_{2} \mathrm{O} / \mathrm{MeOH} \\
4 / 1\end{array}$ & HCOONa; 1.25 & 25 & 73 \\
\hline $15^{[f]}$ & $1 \mathrm{c}$ & $\begin{array}{l}\mathrm{H}_{2} \mathrm{O} / \mathrm{EtOH} \\
4 / 1\end{array}$ & HCOONa; 1.25 & 40 & 79 \\
\hline $16^{[f]}$ & $1 \mathrm{c}$ & $\begin{array}{l}\mathrm{H}_{2} \mathrm{O} / \mathrm{DMF} \\
4 / 1\end{array}$ & HCOONa; 1.25 & 32 & 72 \\
\hline
\end{tabular}

[a] Reaction conditions: $0.00625 \mathrm{mmol}\left[\mathrm{Ru}(p-\mathrm{cym}) \mathrm{Cl}_{2}\right]_{2}, 2 \mathrm{mg} \mathrm{CS} 1,1 \mathrm{~cm}^{3}$ solvent, $0.25 \mathrm{mmol}$ ketone, room temperature ( $\left.\mathrm{rt}, 24 \pm 1{ }^{\circ} \mathrm{C}\right), 46 \mathrm{~h}$; [b] Conversion of $1 \mathrm{a}, \mathbf{1} \mathrm{b}$ or $1 \mathrm{c} ;$ [c] The ee determined by gas-chromatography (GC), configuration of the excess enantiomers were assigned as $S$ based on the optical rotation of the isolated products and literature data; ${ }^{[13]}[\mathrm{d}]$ Using $5 \mathrm{mg}$ pre-prepared Ru-CS1 complex; [e] Reaction temperature $50^{\circ} \mathrm{C}$; [f] Reaction time $70 \mathrm{~h}$

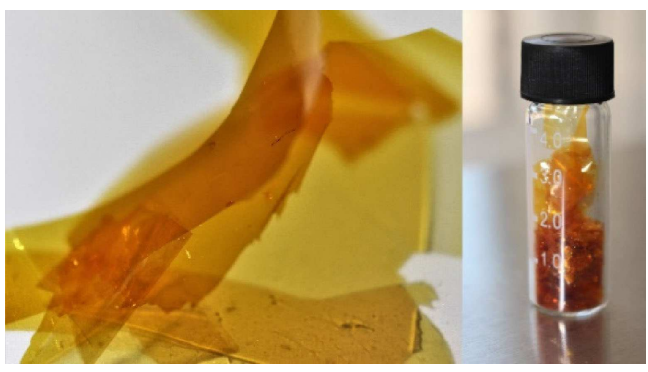

Figure 2. Photographs of the ex situ prepared Ru-CS1.

\section{Scope of the Catalytic System: ETH of Acetophenone Derivatives}

Encouraged by the enantioselectivities obtained in the ETH of the above ketones, we examined the effect of various substituents on the phenyl ring and the ETH of other aryl methyl ketones. Selected results obtained in reactions of $\mathbf{1} \mathbf{b}-\mathbf{1} \mathbf{y}$ as compared with $\mathbf{1} \mathbf{a}$, resulting in 1 -arylethanols $\mathbf{2} \mathbf{b}-\mathbf{2} \mathbf{y}$ are shown in Figure 3. 


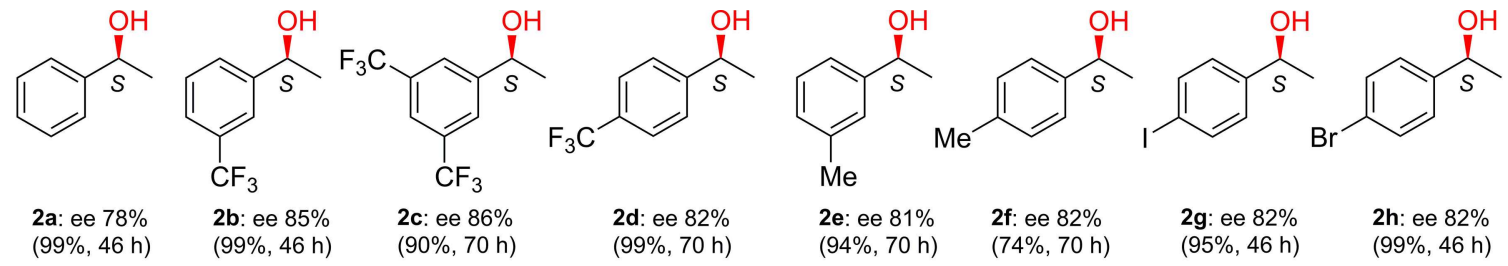<smiles>CC(O)c1cccc(Br)c1</smiles>

2i: ee $80 \%$ $(99 \%, 70 \mathrm{~h})$<smiles>CC(O)c1ccccc1Br</smiles>

2j: ee $51 \%$ $(98 \%, 70$ h)<smiles>CC(O)c1ccc(Cl)cc1</smiles>

2k: ee $79 \%$ (93\%, 70 h)<smiles>C[C@@H](O)c1cccc(Cl)c1</smiles>

21: ee $80 \%$ $(99 \%, 46 \mathrm{~h})$<smiles>CC(O)c1ccc(F)cc1</smiles>

2m: ee $71 \%$ $(92 \%, 70 \mathrm{~h})$<smiles>C[C@@H](O)c1cc(F)ccc1F</smiles>

2n: ee $64 \%$ $(99 \%, 46 \mathrm{~h})$<smiles>C[C@H](O)c1c(F)cccc1F</smiles>

$(99 \%, 46 \mathrm{~h})$<smiles>C[C@H](O)c1c(F)c(F)c(F)c(F)c1F</smiles>

$2 p$ : ee $50 \%$ $(99 \%, 46$ h)<smiles>COc1ccc(C(C)O)cc1</smiles><smiles>CC(O)c1ccccc1[N+](=O)[O-]</smiles><smiles>CC(O)c1ccsc1</smiles>

$\begin{array}{llll}\mathbf{2 v} \text { : ee } 56 \% & \text { 2w: ee } 57 \% & \text { 2x: ee } 77 \% & \text { 2y: ee } 77 \%\end{array}$ $(76 \%, 70 \mathrm{~h}) ; \quad(88 \%, 70 \mathrm{~h}) \quad(88 \%, 70 \mathrm{~h}) ; \quad(96 \%, 46 \mathrm{~h})$ ee $54 \%(73 \%)^{[a]} \quad$ ee $76 \%(90 \%)^{[a]}$

Figure 3. Enantioselectivities obtained in the ETH of aryl methyl ketones using in situ formed Ru-chitosan complex (conversions and reaction times are in brackets). Reaction conditions: $0.00625 \mathrm{mmol}\left[\mathrm{Ru}(p-c y m) \mathrm{Cl}_{2}\right]_{2}, 2 \mathrm{mg} \mathrm{CS} 1,0.25 \mathrm{mmol}$ ketone, $1.25 \mathrm{mmol} \mathrm{HCOONa}, 1 \mathrm{~cm}^{3} \mathrm{H}_{2} \mathrm{O} / \mathrm{iPrOH} 4 / 1, \mathrm{rt}$. [a] Results obtained using $5 \mathrm{mg}$ ex situ prepared Ru-CS1.

Substituents with both electron withdrawing and releasing inductive effects, such as $\mathrm{CF}_{3}, \mathrm{Me}, \mathrm{I}, \mathrm{Br}, \mathrm{Cl}$ in meta or para positions (1 $\mathbf{b}-\mathbf{1} \mathbf{i}, \mathbf{1} \mathbf{k}, \mathbf{1} \mathbf{l})$, increased the ee value as compared with acetophenone. In contrast, in the presence of substituents having electron withdrawing and releasing mesomeric effects, i.e. $\mathrm{NO}_{2}$ or OMe (1 q, $\left.1 \mathrm{r}, 1 \mathrm{t}, 1 \mathrm{u}\right)$, the ee values decreased.

Substituents in ortho positions irrespective of their character decreased significantly the enantioselectivity $(\mathbf{1} \mathbf{j}, \mathbf{1} \mathbf{s}, \mathbf{1} \mathbf{v}, \mathbf{1} \mathbf{w})$, ascribed to their unfavorable steric effects. This is supported by the lower decrease obtained in the ETH of 10 substituted with fluorine in both ortho positions as compared with bulkier functional groups, such as $\mathrm{Br}$, OMe or $\mathrm{NO}_{2}$. The heteroaromatic ketones $1 \mathrm{x}, 1 \mathrm{y}$ gave similar enantioselectivities as $1 \mathrm{a}$. The ex situ prepared material Ru-CS1 also provided similar results as the in situ obtained catalyst in the ETH of ketones $1 \mathbf{v}$ and $1 \mathbf{x}$.

The above results showed that this asymmetric catalytic system has broad applicability and can afford fairly good enantioselectivities in the ETH of several acetophenone derivatives. It must be mentioned that in the reaction of many derivatives the ee surpassed the previously reported highest values obtained using chitosan or its derivatives as chirality source.

\section{Scope of the Catalytic System: ETH of Various Ketones}

Next, we attempted the ETH of prochiral ketones of various structures using ketones $\mathbf{3 a - 3}$, resulting in chiral alcohols $4 \mathrm{a}-$ $4 \mathbf{k}$ (Figure 4). Increasing the alkyl chain from Me to Et and further to Pr gradually decreased the conversion and the ee (see $4 \mathrm{a}, 4 \mathrm{~b}$ ) as well as the $\alpha$-branched alkyl chain in isobutyrophenone $3 \mathrm{c}$. The ex situ prepared Ru-CS1 also gave poor results in the ETH of both $\mathbf{3 a}$ and $\mathbf{3} \mathrm{c}$. Aromatic ketones activated by electron withdrawing groups, such as $\mathrm{COOMe} \mathrm{CF}_{3}$ or $\mathrm{CH}(\mathrm{OEt})_{2}(3 \mathrm{~d}-3 \mathrm{f})$, were hydrogenated in low, up to $48 \%$ enantioselectivities. Distancing the keto group from the aromatic moiety $(\mathbf{3} \mathbf{g}, \mathbf{3 h}$ ) also decreased the ee, however, by inclusion of an oxygen between the phenyl and the ketone moieties the ee slightly increased ( $\mathbf{3} \mathbf{i}$ ) as compared with $\mathbf{3 h}$. In the ETH of aliphatic prochiral methyl ketones both bearing electron releasing $(t \mathrm{Bu}, \mathbf{3} \mathbf{j})$ or electron withdrawing (COOEt, $\mathbf{3} \mathbf{~ k})$ groups low ee values were reached.

According to these results, although the enantioselective transfer hydrogenation of structurally very diverse prochiral ketones is possible using the in situ formed chiral Ru-chitosan complex, good ee values were obtained only in reactions of properly substituted aryl methyl ketones. 
<smiles>CCC(O)c1ccccc1</smiles>

4a: ee $60 \%$ (66\%, 46 h); ee $58 \%(69 \%)^{[a]}$

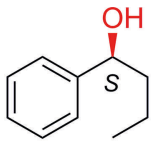

4b: ee $42 \%$ $(58 \%, 70 \mathrm{~h})$<smiles>[R]C(c1ccccc1)C(F)(F)F</smiles><smiles>CCOC(O)C(O)c1ccccc1</smiles><smiles>C[C](O)Cc1ccccc1</smiles>

4e: ee $48 \%$ $(100 \%, 70 \mathrm{~h})$ 4f: ee $26 \%$
$(97 \%, 70$ h)<smiles>C[C@@H](O)CCc1ccccc1</smiles>

4h: ee $30 \%$ $(82 \%, 70 \mathrm{~h})$<smiles>COC(=O)[C@H](O)c1ccccc1</smiles>

\section{4c: ee $48 \%$}

4d: ee $47 \%$ (40\%, 70 h); ee $47 \%(40 \%)^{[a]}$<smiles>O[C@H]1CCCCc2ccccc21</smiles>

6a: ee $65 \%$ $(77 \%, 70 \mathrm{~h})$

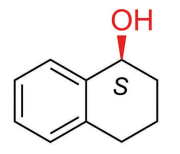

6b: ee $93 \%$ $(61 \%, 70 \mathrm{~h})$

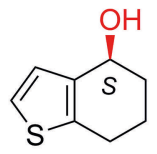

6c: ee $92 \%$

(73\%, $120 \mathrm{~h})$; ee $91 \%(75 \%)^{[a]}$

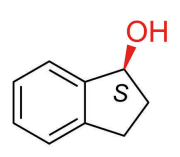

6d: ee $88 \%$ $(80 \%, 70$ h)<smiles>O[C@H]1CCc2ccc(C(F)(F)F)cc21</smiles>

6e: ee $92 \%$ (91\%, 70 h)<smiles>O[C@H]1CCOc2ccccc21</smiles>

6f: ee $96 \%$ (98\%, 46 h); ee $96 \%(99 \%)^{[a]}$<smiles>O[C@H]1CCOc2ccc(Cl)cc21</smiles>

6g: ee $96 \%$ (99\%, 46 h)<smiles>Cc1ccc2c(c1)[C@H](O)CCS2</smiles>

6h: ee $97 \%$ (99\%, 46 h); ee $96 \%(98 \%)^{[a]}$<smiles>O[C@H]1CCSc2ccc(Cl)cc21</smiles>

6j: ee $97 \%$ $(99 \%, 46 \mathrm{~h})$<smiles>O[C@H]1CSCc2ccccc21</smiles>

6k: ee $92 \%$ $(18 \%, 120 \mathrm{~h})$
Figure 4. Enantioselectivities obtained in the ETH of various ketones using in situ formed Ru-chitosan complex (conversions and reaction times are given in brackets). Reaction conditions: $0.00625 \mathrm{mmol}\left[\mathrm{Ru}(p-\mathrm{cym}) \mathrm{Cl}_{2}\right]_{2}, 2 \mathrm{mg}$ CS1, $0.25 \mathrm{mmol}$ ketone, $1.25 \mathrm{mmol} \mathrm{HCOONa}, 1 \mathrm{~cm}^{3} \mathrm{H}_{2} \mathrm{O} / \mathrm{PPrOH} 4 / 1$, rt. [a] Results obtained using $5 \mathrm{mg}$ ex situ prepared Ru-CS1.

\section{Scope of the Catalytic System: ETH of Cyclic Ketones}

Although, increasing the alkyl chain length of aryl alkyl ketones resulted in diminished ee values as compared with $1 \mathrm{a}$, we hoped that closing this chain in a rigid ring condensed with the aromatic moiety may have beneficial effect on the enantioselectivity. Thus, we decided to investigate the ETH of cyclic aromatic ketones $\mathbf{5} \mathbf{a}-\mathbf{5} \mathbf{k}$ (see Scheme 2).

Surprisingly high enantioselectivities were obtained in the ETH of six-membered carbocyclic ketones 1-tetralone ( $5 \mathbf{b})$ and $5 \mathrm{c}$, respectively (Figure 5). Increase of the ring size to seven (1benzosuberone, $5 \mathrm{a}$ ), lowered significantly the ee value, possibly due to the higher flexibility of this ring as compared with the six-membered cycle. The ee attained in the ETH of the fivemembered cyclic ketone 1 -indanone ( $5 \mathrm{~d}$ ) approached the value obtained with 1-tetralone, supporting the assumption that the rigidity of the aliphatic ring has crucial role in reaching high ee. Moreover, the presence of the trifluoromethyl substituent on the aromatic ring (5e) further increased the ee to over $90 \%$. Delightfully, high enantioselectivities (ee 96-97\%) were obtained in reactions of heterocyclic compounds, such as 4-

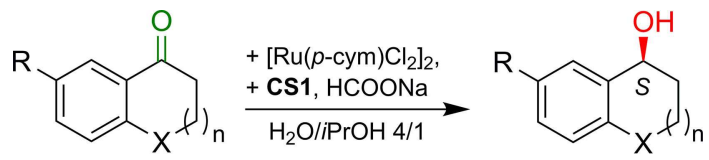

5a - 5k

$\mathrm{R}: \mathrm{H}, \mathrm{Cl}, \mathrm{Me}, \mathrm{CF}_{3}$;

$\mathrm{X}: \mathrm{CH}_{2}, \mathrm{O}, \mathrm{S} ; \mathrm{n}: \mathrm{O}-2$
Figure 5. Enantioselectivities obtained in the ETH of cyclic ketones using in situ formed Ru-chitosan complex (conversions and reaction times are given in brackets). Reaction conditions: $0.00625 \mathrm{mmol}\left[\mathrm{Ru}(p-c y m) \mathrm{Cl}_{2}\right]_{2}, 2 \mathrm{mg}$ CS1, 0.25 mmol ketone, $1.25 \mathrm{mmol} \mathrm{HCOONa,} 1 \mathrm{~cm}^{3} \mathrm{H}_{2} \mathrm{O} / \mathrm{iPrOH} 4 / 1$, rt. [a] Results obtained using $5 \mathrm{mg}$ ex situ prepared Ru-CS1.

chromanone, 4-thiochromanone and their substituted derivatives $(\mathbf{5} \mathbf{f}-\mathbf{5} \mathbf{j})$ either with the in situ or with ex situ prepared catalyst (the latter in the ETH of $\mathbf{5 c}, \mathbf{5 f}$ and $\mathbf{5 h}$ ). The position of the heteroatom was vital for obtaining high ee, evidenced by the lower value attained with 4-isothiochromanone $(\mathbf{5 k})$. Accordingly, we presume that the heteroatoms also interact with the chiral catalyst leading to an additional directing effect.

\section{Studies on the Structure of the Chiral Catalyst}

We continued our studies with the goal of gathering information on the structure of the chiral Ru catalyst. For this purpose, we attempted to identify the requirements, which must suit the efficient ligand. Accordingly, we have used several types of commercially available chitosan (CS1, CS2 and CS3), D-glucosamine (GluA, the monomer of this biopolymer), D-galactosamine (GalA), chitin (CT), and several other CS derivatives (CS11, CS12 and CS13) having protected amino and/or hydroxyl groups, which were prepared from CS1 by known methods. The preparation procedures are shown in Scheme 3. ${ }^{[14]}$ Transformation of CS1 was monitored by Fouriertransform infrared spectroscopy (FT-IR, Figure SI1, Supporting Information). ${ }^{[15]}$

As test reaction the ETH of 4-chromanone $(\mathbf{5} \mathbf{f})$ was selected (Table 2), in which excellent enantioselectivity could be obtained using CS1 ligand (see Figure 5 and Table 2, entry 2). Without using chiral ligand the reaction did not proceed. The high molecular weight (CS1) and the low viscosity (CS3) chitosan performed similarly, with the former being slightly 


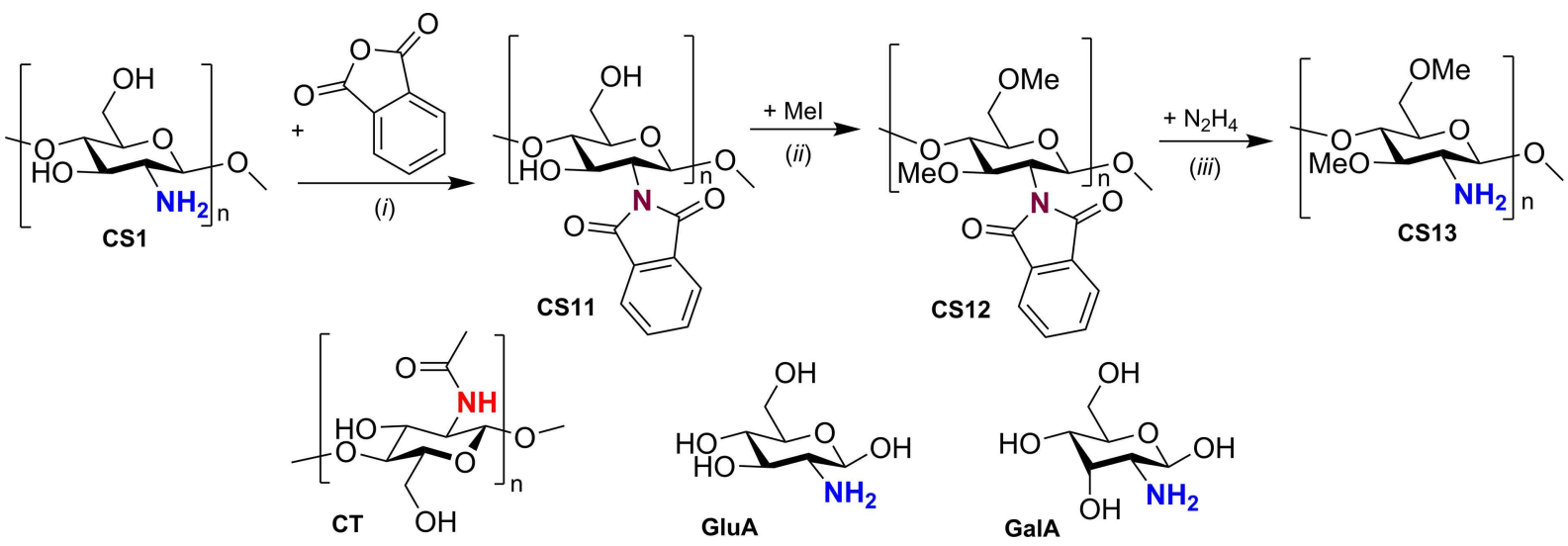

Scheme 3. Preparation methods of chitosan derivatives and the structure of other ligands tested in the ETH of $4-\mathrm{chromanone}(i) \mathrm{DMF} / \mathrm{H}_{2} \mathrm{O} 95 / 5,100{ }^{\circ} \mathrm{C}, 24 \mathrm{~h}$; (ii) $\mathrm{NaH}, \mathrm{DMF}, 0^{\circ} \mathrm{C}, 15 \mathrm{~h}$; (iii) $\mathrm{MeOH} / \mathrm{H}_{2} \mathrm{O} 4 / 1,80^{\circ} \mathrm{C}, 24 \mathrm{~h}$.

\begin{tabular}{|c|c|c|c|}
\hline \multirow[t]{2}{*}{ Entry } & \multirow{2}{*}{ Ligand } & \multirow[t]{2}{*}{ 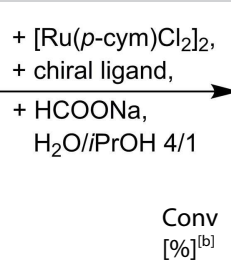 } & \multirow{2}{*}{$\begin{array}{l}e e \\
{[\%]^{[b]}}\end{array}$} \\
\hline & & & \\
\hline 1 & - & 3 & 0 \\
\hline 2 & CS1 & $>99$ & 96 \\
\hline $3^{[c]}$ & CS1 & $>99$ & 95 \\
\hline 4 & CS2 & 60 & 89 \\
\hline 5 & $\mathrm{CS} 3$ & 94 & 96 \\
\hline 6 & CT & 40 & 85 \\
\hline 7 & GluA.HCI & 22 & 44 \\
\hline 8 & GalA.HCl & 12 & 40 \\
\hline 9 & CS11 & 5 & 26 \\
\hline 10 & $\mathrm{CS} 12$ & 4 & 8 \\
\hline 11 & CS13 & 80 & 93 \\
\hline
\end{tabular}

[a] Reaction conditions: $0.00625 \mathrm{mmol}\left[\mathrm{Ru}(p-\mathrm{cym}) \mathrm{Cl}_{2}\right]_{2}, 2 \mathrm{mg}$ chitosan or $0.012 \mathrm{mmol}$ ligand, $0.25 \mathrm{mmol}$ ketone, $1.25 \mathrm{mmol} \mathrm{HCOONa}, 1 \mathrm{~cm}^{3} \mathrm{H}_{2} \mathrm{O} /$ iPrOH 4/1, rt, $46 \mathrm{~h}$; [b] Conversions and enantioselectivities determined by GC-FID; the absolute configuration of the excess enantiomer was $S_{i}[c] 50^{\circ}$ C, $22 \mathrm{~h}$.

more efficient (entries 2, 5). Accordingly, the molecular weight (viscosity) is not a crucial property for having an efficient chiral ligand. Using the former (CS1) the reaction took only $22 \mathrm{~h}$ at higher temperature $\left(50^{\circ} \mathrm{C}\right)$ with almost identical enantioselectivity.

The low molecular weight chitosan (CS2) having similar degree of deacetylation as CS1 (see Experimental section) was much less appropriate ligand, giving lower conversion and ee (entry 4). A single chitosan monomer (GluA) was found much less efficient, than chitosan (entry 7), similarly with its stereoisomer GalA (entry 8).

To trace down the role of the functional groups in bonding the metal cation three chitosan derivatives were prepared. As a consequence of transforming the amino group of CS1 to phthalimide (CS11) and further protecting the hydroxyl groups by methylation (CS12) the conversions were similar as without any ligand (entries 9, 10), attributable to lack of complex formation with these derivatives. By deprotecting the amino group again, we obtained an efficient ligand (CS13), which had a performance approaching CS1 (entry 11). Accordingly, free amino groups are essential to form active complex, whereas the hydroxyl groups are not crucial, however their role in the formation of the active complex with CS may not be excluded, knowing that chiral 1,2-aminoalcohol ligands are also efficient in $\mathrm{ETH}^{[4 \mathrm{c}, 16]}$ The complex formed with commercial chitin also had some activity (entry 6), which may be ascribed either to some degree of deacetylation of this material or to weak binding to the metal by amide and/or hydroxyl groups.

In the ETH of various ketones the material prepared ex situ (Ru-CS1, Figure 2) gave very similar results with those obtained with the catalyst formed in situ (see Table 1, Figures 3, 4 and 5). The SEM micrograph of the Ru-CS1 showed the formation of a film-like material having smooth surface, which could be crushed giving sharp edges (Figure 6 (a)). The SEM-EDX elemental map showed uniformly distributed $\mathrm{N}$ in the sample. The distribution of the Ru was less uniform with areas of CS where metal could be barely detected (Figure 6 (b)). The atomic ratio of $\mathrm{N} / \mathrm{Ru}$ introduced during preparation was close to one (0.94). Accordingly, even under these conditions (Ru in slight excess) the metal bonding capacity of CS1 was not fully exploited. This indicated that besides the predominant formation of a pre-catalyst with a monomer/Ru 1/1 ratio, unreacted $\mathrm{Ru}$ precursor or species in which one monomer bonded more cations may exist in this material. The EDX spectrum of the sample indicated a $\mathrm{Cl} / \mathrm{Ru}$ ratio close to 2 , similarly with that of the precursor (Figure SI2, Supporting Information). Hence no $\mathrm{HCl}$ was eliminated and mono-dentate coordinative bonding of the biopolymer to the metal may be assumed in the precatalyst.

Subsequently, we examined the interaction of the CS and $\mathrm{Ru}$ by Fourier-transform mid-infrared (FT-IR) and far-infrared spectroscopy (FT-far-IR) using this ex situ prepared pre-catalyst. The FT-IR spectra of the Ru precursor, chitosan and Ru-CS1, respectively are shown in Figure 7. Alterations detected in the spectrum of the Ru-CS1 material as compared with that of CS1, 

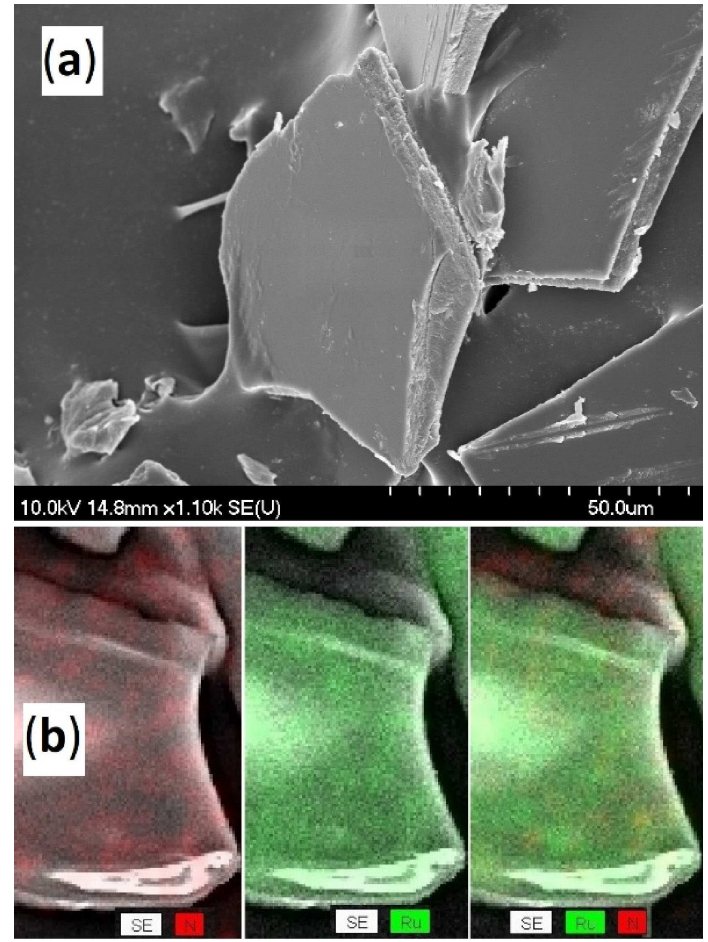

Figure 6. SEM micrograph (a) and SEM-EDX elemental maps (b) (N: red, Ru: green) of the ex situ prepared Ru-CS1.

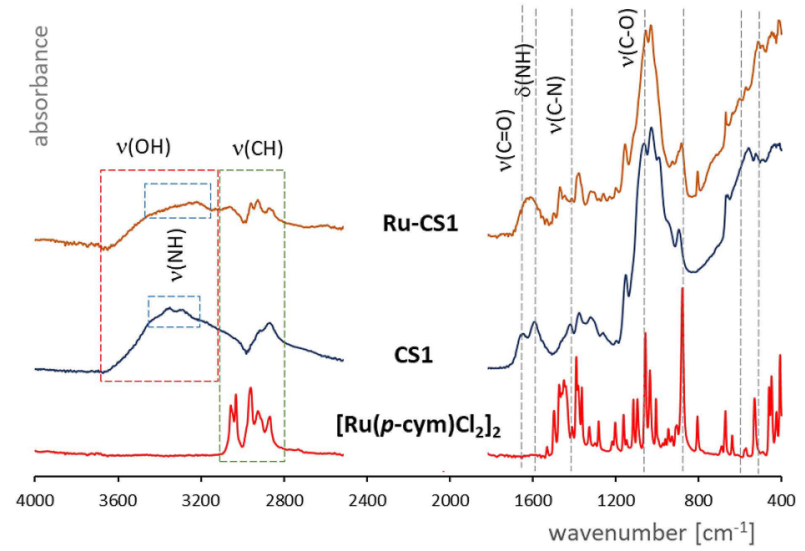

Figure 7. FT-IR spectra of $\left[\mathrm{Ru}(p-c y m) \mathrm{Cl}_{2}\right]_{2}$, chitosan CS1 and Ru-CS1.

were similar with those described previously for metal-chitosan complexes. ${ }^{[15 b, 17]}$ The intensity of the broad band at 3150 $3600 \mathrm{~cm}^{-1}$ corresponding to the overlapped $v(\mathrm{O}-\mathrm{H})$ and $v(\mathrm{~N}-\mathrm{H})$ vibrations decreased and the latter shifted to lower wavenumbers. However, the hydroxyl groups still gave a strong band, indicating that most of these are not involved in bonding the $\mathrm{Ru}$. In the spectrum of Ru-CS1 the $v(\mathrm{C}-\mathrm{H})$ vibrations corresponding to the $p$-cym ligand also appeared, showing the formation of a half-sandwich type complex. The bands $\delta(\mathrm{N}-\mathrm{H})$ at $1595 \mathrm{~cm}^{-1}$ and $v(\mathrm{C}=0)$ at $1655 \mathrm{~cm}^{-1}$, the latter attributed to the residual acetamido groups, disappeared and a broad band centered at $1620 \mathrm{~cm}^{-1}$ developed, as a consequence of bonding

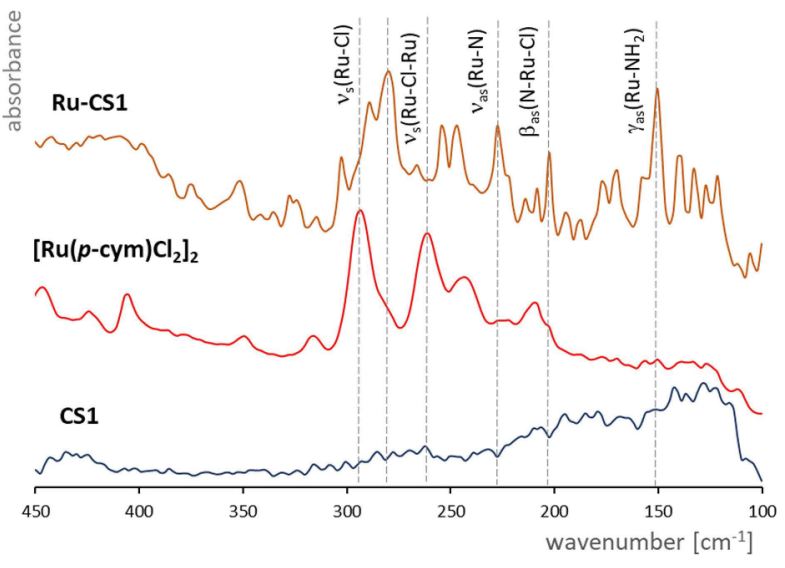

Figure 8. FT-far-IR spectra of CS1, $\left[\mathrm{Ru}(p-\mathrm{cym}) \mathrm{Cl}_{2}\right]_{2}$ and Ru-CS1.

the Ru by amino groups. Similarly, the band in the spectrum of CS1 corresponding to $v(\mathrm{C}-\mathrm{N})$ (at $1420 \mathrm{~cm}^{-1}$ ) was shifted in that of Ru-CS1. Changes of the positions and the intensities of the bands in the $v(C-O)$ region $\left(950-1150 \mathrm{~cm}^{-1}\right)$ were also detected. In the low wavenumber region low intensity bands appeared in the spectrum of Ru-CS1, previously assigned to vibrations of $\mathrm{Ru}-\mathrm{N}$ or $\mathrm{Ru}-\mathrm{Cl}$ bonds. ${ }^{[17 \mathrm{~b}]}$

Identification of bonds formed between the metal and CS was attempted using FT-far-IR (Figure 8). Bands at $293 \mathrm{~cm}^{-1}$ and $264 \mathrm{~cm}^{-1}$ in the spectrum of the Ru precursor are attributed to the $v_{s}(\mathrm{Ru}-\mathrm{Cl})$ stretching vibrations and the $v_{s}(\mathrm{Ru}-\mathrm{Cl}-\mathrm{Ru})$ symmetric vibration of the $\mathrm{Cl}$ bridges. ${ }^{[18]}$ The former band shifted to lower wavenumber $\left(279 \mathrm{~cm}^{-1}\right)$ in the spectrum of RuCS1, whereas the latter disappeared, due to splitting of the precursor dimer by interaction with $\mathrm{CS} 1$. The intense band appeared at $227 \mathrm{~cm}^{-1}$ in the spectrum of Ru-CS1 may be ascribed to $v_{\text {as }}(R u-N)$ vibrations based on far-IR studies of $R u$ halogenoammine complexes. ${ }^{[18 c]}$ Furthermore, bands at 202 and $150 \mathrm{~cm}^{-1}$ were identified as $\beta_{\text {as }}(\mathrm{N}-\mathrm{Ru}-\mathrm{Cl})$ bending and $\gamma_{\text {as }}(\mathrm{Ru}-$ $\mathrm{NH}_{2}$ ) torsional vibrations. In conclusion, the above IR studies indicated the predominant formation of half-sandwich Ruchitosan complexes by $\mathrm{Ru}-\mathrm{N}$ bonding, whereas the $p$-cym ligand and $\mathrm{Ru}-\mathrm{Cl}$ bonds were still present in the pre-catalyst.

The structure of the Ru complex formed in situ in $\mathrm{D}_{2} \mathrm{O}$ was examined by ${ }^{1} \mathrm{H}$ NMR spectroscopy (Figure 9). A solution of CS1 obtained by addition of trifluoroacetic acid (TFA) was used as reference $\left(\mathrm{CS}{ }^{*}{ }^{\mathrm{T}} \mathrm{TFA}\right)$. Signals corresponding to the ring $\mathrm{H}$ of $\mathrm{CS} 1$ were assigned based on literature, where the signal of the anomeric $\mathrm{H}(\mathrm{H} 1)$ was covered by that of HOD. ${ }^{[15 a, 19]}$

In the spectrum recorded in the presence of $\mathrm{Ru}$ (monomerCS1/Ru 1.41) we detected two sets of signals in about $2 / 1$ ratio corresponding to the $p$-cym ligand. The major, broad, unresolved set of signals $(5.60,5.41,2.64 \mathrm{ppm})$ showed formation of a flexible complex with the $p$-cym in its composition (signals corresponding to the two $\mathrm{CH}_{3}$ groups showed similar pattern). We assigned these signals to $\mathrm{H}$ of complexes in which amino groups are coordinated to the $\mathrm{Ru}$, based on previously proposed interaction of aminosaccharide derivatives with $\mathrm{Pd}^{[19 \mathrm{~d}]}$ The well-resolved signal set $(5.24,5.03,2.53 \mathrm{ppm})$ may 


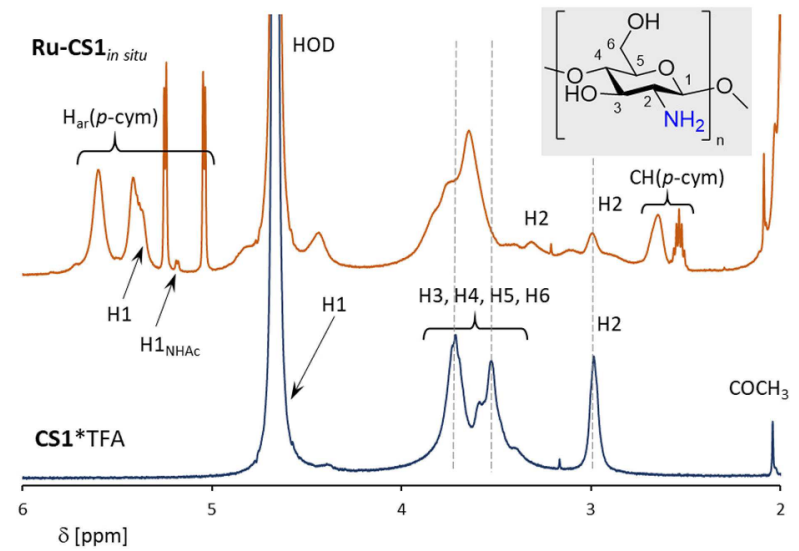

Figure 9. ${ }^{1} \mathrm{H}$ NMR spectra of CS1 ${ }^{*}$ TFA and of the material formed from CS1 (3 mg) and $\left[\mathrm{Ru}(p-c y m) \mathrm{Cl}_{2}\right]_{2}(0.00625 \mathrm{mmol})$ in $\mathrm{D}_{2} \mathrm{O}$.

be attributed to formation of a more rigid half-sandwich type complex in which a glucosamine monomer may act as a bidentate ligand and is coordinated to the metal by two amino groups or by the involvement of hydroxyl and/or acetamido groups. ${ }^{[19 d, 20]}$ Due to the overlapped signals it is not possible to identify certainly the ring $\mathrm{Hs}$, however, one may observe the split of the $\mathrm{H} 2$ signal in two signals. Besides the broad one close to $3 \mathrm{ppm}$, another shifted downfield to $3.3 \mathrm{ppm}$ may also be assigned to $\mathrm{H} 2$. The merged ring $\mathrm{H}$ signals between 3.4-4.0 ppm $(\mathrm{H} 3, \mathrm{H} 4, \mathrm{H} 5, \mathrm{H6})$ gave a relative integral value of 4.5 , accordingly we assume that the signal at $4.4 \mathrm{ppm}$ also corresponds to the $\mathrm{H} 3$ of the complex.

The above characterization methods gave information on the possible structure of the pre-catalyst. However, the composition and the structure of the working chiral catalyst remained unclear. Transformation of this pre-catalyst was visible upon addition of the $\mathrm{H}$-donor and further in the presence of the ketone. To determine the amount of the chiral ligand necessary to obtain the active catalyst we have investigated the effect of the CS1/Ru ratio on the conversion and ee in the ETH of $\mathbf{5} \mathbf{f}$. Results of these investigations are illustrated in Figure 10.

The CS1 amount had significant influence on the conversion at $6.25 \mathrm{mM}$ Ru-precursor concentration. The conversions increased until a $\mathrm{NH}_{2} / \mathrm{Ru}$ of 1 was reached (calculated considering a $75 \%$ deacetylation degree for CS1), when complete transformation is obtained and further changes cannot be monitored. Using halved metal concentration showed a slow linear increase of the conversion by raising the CS1 amount.

Importantly, at both $\mathrm{Ru}$ amounts even at the lowest $\mathrm{NH}_{2} / \mathrm{Ru}$ ratios $(<1)$, the ee reached values close to the best obtained in these experiments ( $95 \%$ and $96 \%$, respectively). Accordingly, even at low CS1 amount the enantioselective catalyst is already formed, though at high Ru concentrations the metal was not completely transformed to catalytically active species. The conversion may also be influenced by the solubility of the complex. A soluble pre-catalyst results by mixing the Ruprecursor and CS1 (Figure 10 (a)), which is transformed to a yellow precipitate following addition of HCOONa (Figure 10 (b)).

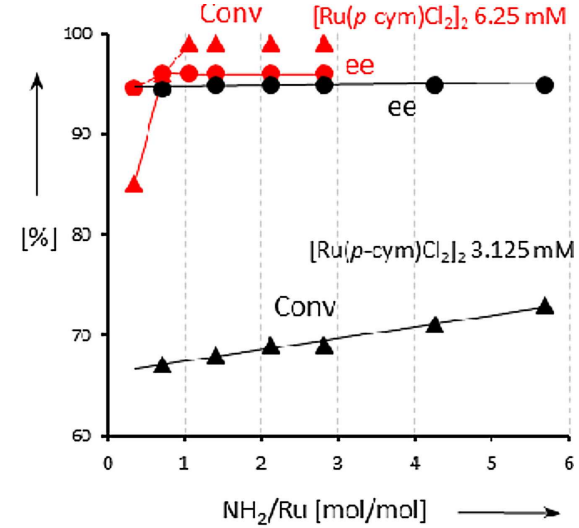

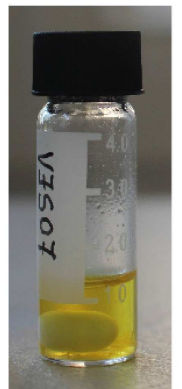

(a)

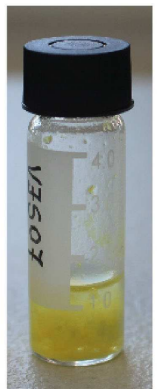

(b)

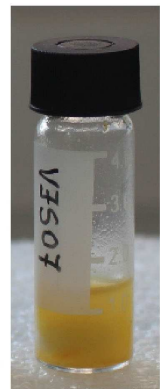

(c)
Figure 10. Effect of the CS1/Ru ratio on the conversion (triangles) and ee (circles) in the ETH of $\mathbf{5 f}$. Reaction conditions: $\left[\mathrm{Ru}(p-c y m) \mathrm{Cl}_{2}\right]_{2}$ concentration $6.25 \mathrm{mM}$ and $3.125 \mathrm{mM}$ (red and black symbols), $0.25 \mathrm{mmol} 5 \mathrm{f}, 1.25 \mathrm{mmol}$ $\mathrm{HCOONa}, 1 \mathrm{~cm}^{3} \mathrm{H}_{2} \mathrm{O} / \mathrm{PPOH} 4 / 1,30^{\circ} \mathrm{C}, 24 \mathrm{~h}$; below are the photographs of the in situ formed soluble pre-catalyst (a), the complex resulted following addition of $\mathrm{HCOONa}(\mathrm{b})$ and the product mixture after $24 \mathrm{~h}$ reaction (c) using 3.125 mM Ru-precursor and $\mathrm{NH}_{2} / \mathrm{Ru} 2.1$.

This complex is further transformed during ETH shown by the solubilized catalyst, which also changed its color to pale orange (Figure 10 (c)). When high amounts of CS1 were used, the excess polymer remained undissolved.

According to the widely accepted concerted outer-sphere type mechanism of the transfer hydrogenation of prochiral ketones with half-sandwich complexes, Ru-hydride is formed by addition of the H-donor. ${ }^{[21]}$ Thus, the yellow precipitate (Figure 10 (b)) could be a similar Ru-hydride complex formed from the Ru-chitosan pre-catalyst. The heterogeneous nature of this complex makes difficult to determine its composition based on the above results, however, the continuous increase in the conversion with the CS1 amount showed the possible participation of more than 1 monomer in the formation of the catalyst. Based on previous studies on the structure of chitosan complexes formed with metals and the above described results we assume the formation of a pre-catalyst and active hydride complexes having structures as illustrated in Scheme 4. 


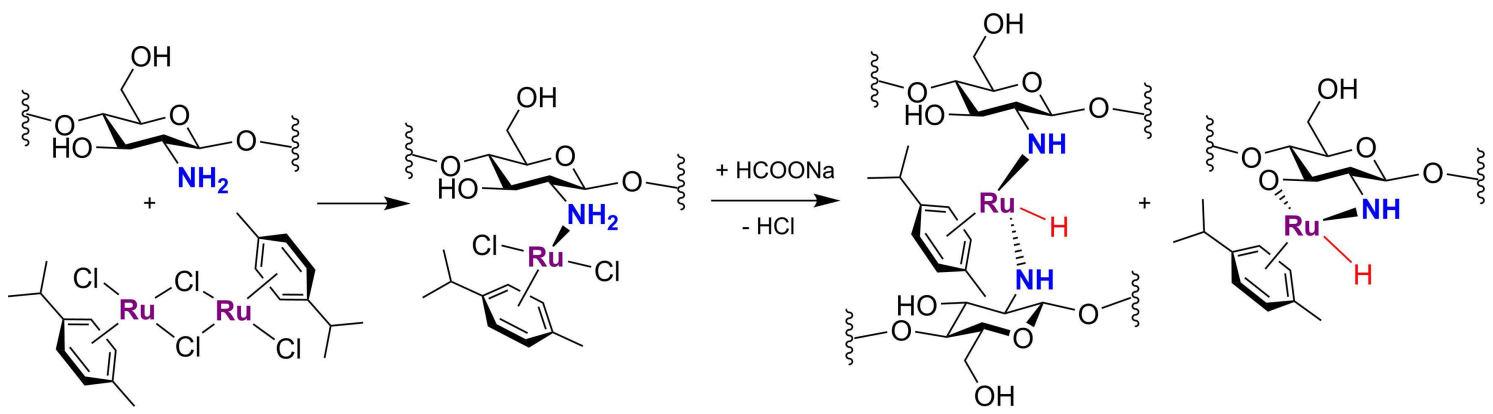

Scheme 4. Suggested structure of the pre-catalyst formed from chitosan and $\left[\mathrm{Ru}(p-\mathrm{cym}) \mathrm{Cl}_{2}\right]_{2}$ and the probable active species resulted by addition of $\mathrm{HCOONa}$.

\section{Preparative Applicability of the Chiral Ru-CS1 Catalyst}

Having in hand a catalytic system, which affords good enantioselectivities in the ETH of several acetophenone derivatives and cyclic ketones we examined the practical value of the Ru complex bearing unmodified CS1 as ligand. For this purpose, we carried out reactions at $1 \mathrm{mmol}$ scale (4-fold) increasing proportionally the metal precursor and the solvent amount and using doubled quantities of $\mathrm{H}$-donor. The yields of the isolated optically enriched products are summarized in Table 3.

\begin{tabular}{|c|c|c|c|c|c|}
\hline Entry & Product & $\begin{array}{l}\begin{array}{l}+[\mathrm{Ru}(p-\mathrm{cym} \\
\mathrm{n} \quad \mathrm{CS} 1, \mathrm{HCO}\end{array} \\
\begin{array}{l}\mathrm{H}_{2} \mathrm{O} / \mathrm{iPrO} \\
\text { Reaction time } \\
{[\mathrm{h}]}\end{array}\end{array}$ & $\begin{array}{l}\text { Conv } \\
{[\%]} \\
{[\%]}\end{array}$ & $\overbrace{X^{-(j)}}^{\mathrm{OH}}$ & $\begin{array}{l}e e^{[\mathrm{d}]} \\
{[\%]}\end{array}$ \\
\hline 1 & $2 a$ & 48 & 99 & 84 & 79 \\
\hline 2 & $2 b$ & 72 & 99 & 85 & 84 \\
\hline 3 & $2 c$ & 96 & 85 & 73 & 85 \\
\hline 4 & $2 d$ & 48 & 98 & 82 & 83 \\
\hline 5 & $2 \mathrm{e}$ & 75 & 92 & 80 & 82 \\
\hline 6 & $2 f$ & 96 & 75 & 72 & 81 \\
\hline 7 & $2 \mathrm{~g}$ & 72 & 93 & 83 & 82 \\
\hline 8 & $2 \mathrm{~h}$ & 72 & 99 & 86 & 82 \\
\hline 9 & $2 i$ & 72 & 99 & 85 & 79 \\
\hline 10 & $2 k$ & 96 & 92 & 81 & 79 \\
\hline 11 & 21 & 72 & 99 & 95 & 78 \\
\hline 12 & $2 m$ & 96 & 90 & 75 & 72 \\
\hline 13 & 20 & 72 & 99 & 80 & 73 \\
\hline 14 & $2 r$ & 96 & 90 & 84 & 75 \\
\hline 15 & $6 b$ & 168 & 65 & 60 & 91 \\
\hline 16 & $6 c$ & 168 & 80 & 66 & 91 \\
\hline 17 & $6 d$ & 96 & 80 & 64 & 86 \\
\hline 18 & $6 e$ & 96 & 90 & 68 & 93 \\
\hline 19 & $6 f$ & 48 & 98 & 87 & 95 \\
\hline 20 & $6 \mathrm{~g}$ & 72 & 98 & 86 & 95 \\
\hline 21 & $6 \mathrm{~h}$ & 48 & 99 & 88 & 96 \\
\hline 22 & $6 i$ & 72 & 99 & 87 & 96 \\
\hline 23 & $6 j$ & 72 & 99 & 90 & 97 \\
\hline
\end{tabular}

[a] Reaction conditions: $0.025 \mathrm{mmol}\left[\mathrm{Ru}(p-\mathrm{cym}) \mathrm{Cl}_{2}\right]_{2}, 10 \mathrm{mg} \mathrm{CS} 1,1 \mathrm{mmol}$ ketone, $2.5 \mathrm{mmol} \mathrm{HCOONa}, 4 \mathrm{~cm}^{3} \mathrm{H}_{2} \mathrm{O} / \mathrm{PPrOH} 4 / 1$, rt; [b] Conversions determined by $\mathrm{GC} ;[\mathrm{c}$ ] Isolated product yields determined following purification by flash chromatography; [d] The ee determined by gaschromatography (GC), the configuration of the excess enantiomers was assigned as $S^{[13]}$
Under the above conditions the reactions needed more time, however similar conversions and very close ee values were reached as compared with the runs carried out at lower scale $(0.25 \mathrm{mmol})$. Accordingly, the optically enriched alcohols were isolated in good yields. Further the ETH of $\mathbf{1} \mathbf{c}, \mathbf{1} \mathbf{g}, \mathbf{5} \mathbf{f}$ and $5 \mathrm{~h}$ were also carried out at gram scale with 5 or $8 \mathrm{mmol}$ ketones, under identical conditions, using proportionally increased catalyst, chitosan and H-donor amounts. The corresponding alcohols were prepared in high yields following flash chromatographic purification (Figure 11). Moreover, close to optically pure (S)-6f and (S)-6h were obtained in good yields following a single recrystallization of the products in hexane.

\section{Conclusions}

Our attempts to develop a green and sustainable reduction method using the biocompatible and degradable biopolymer chitosan of natural origin led to an aqueous catalytic system in which high enantioselectivities were obtained in the asymmetric transfer hydrogenation of prochiral ketones using an in situ formed chiral Ru complex as catalyst and HCOONa as hydrogen donor. Acetophenone derivatives were reduced to the corre-<smiles>C[C@H](O)c1cc(C(F)(F)F)cc(C(F)(F)F)c1</smiles>

$0.978 \mathrm{~g}$, yield $76 \%$, ee $85 \%$<smiles>O[C@@H]1CCOc2ccccc21</smiles>

$6 f$<smiles>C[C@H](O)c1ccc(I)cc1</smiles>

$1.102 \mathrm{~g}$, yield $89 \%$, ee $82 \%$<smiles>O[C@@H]1CCSc2ccccc21</smiles>

$6 \mathrm{~h}$
$1.118 \mathrm{~g}$, yield $93 \%$, ee $95 \%$; $\quad 1.130 \mathrm{~g}$, yield $85 \%$, ee $95 \%$; $0.996 \mathrm{~g}$, yield $83 \%$, ee $99.8 \%{ }^{[\mathrm{a}]} \quad 1.002 \mathrm{~g}$, yield $75 \%$, ee $99 \%{ }^{[\mathrm{a}]}$

Figure 11. Products prepared at gram scale (using $5 \mathrm{mmol} \mathbf{1 c}, \mathbf{g}$ or $8 \mathrm{mmol}$ $\mathbf{5 f}$ or $\mathbf{5 h}$ ) purified by flash-chromatography; [a] products obtained following an additional recrystallization from hexane. 
sponding 1-arylethanols in up to $86 \%$ ee, unprecedented until now in the presence of natural CS as chirality source. Moreover, cyclic aryl ketones were hydrogenated in surprisingly high, over $90 \%$ ee, the best results, up to $97 \%$, being obtained in reactions of heterocyclic compounds, such as 4-chromanone or 4-thiochromanone and their substituted derivatives. These outstanding results may be rationalized by the rigidity of the cyclic ketones, i.e. the steric hindrances imposed by the ring. In case of the heterocyclic compounds this effect could be complemented by possible interactions of the heteroatoms with the catalyst, which may also have a directing effect on the substrate during ETH.

A pre-catalyst prepared from the Ru-precursor and CS was equally efficient as the in situ formed complex, was much easier to handle and could be stored for several months. This material was characterized using scanning electron microscopy, infrared and NMR spectroscopy. Although coordination of the CS to Ru could be demonstrated, it was shown the presence of complexes of both high and low rigidity in the presence of excess CS. In these complexes CS interacts with the metal through amino groups, however, in some species the role of the hydroxyl or even acetamido groups in bonding to the $\mathrm{Ru}$ could not be excluded. Based on results obtained using CS derivatives and that of a study on the CS/metal ratio we reached to the conclusion, that the amino groups have crucial role in the formation of the active complex and probably the metal interacts with two glucosamine monomers to form the active complex. Results obtained in the present study and previously published data were used to suggest possible structures for the pre-catalyst and the active complex. However, further examination of the catalyst composition and structure will be carried out in the near future and will be reported in due course.

\section{Experimental Section}

\section{Materials and methods}

High molecular weight chitosan (CS1, $M_{w}: 310,000-375,000 \mathrm{Da}$, $\geq 75 \%$ deacetylated, $\mu 800-2000 \mathrm{cP}$ of 1 wt. $\%$ in $1 \%$ acetic acid), low molecular weight chitosan (CS2, Mw: 50,000-190,000 Da, 75$85 \%$ deacetylated, $\mu 20-300$ cP of $1 \mathrm{wt} . \%$ in $1 \%$ acetic acid) and low viscosity chitosan (CS3, $\mu<200 \mathrm{cP}$ of $1 \mathrm{wt} . \%$ in $1 \%$ acetic acid) were purchased from Sigma-Aldrich and used as received. The Ruprecursor $\left[\mathrm{Ru}(p-\mathrm{cym}) \mathrm{Cl}_{2}\right]_{2}$ was used as received (Sigma-Aldrich). Ketones used in this study were all commercial products and used without purification. The hydrogen donors and analytical grade organic solvents were obtained from commercial sources and used as received. The ex situ prepared material Ru-CS1 was obtained by stirring $38 \mathrm{mg}\left[\mathrm{Ru}(p-c y m) \mathrm{Cl}_{2}\right]_{2}$ and $20 \mathrm{mg}$ CS1 chitosan in $40 \mathrm{~cm}^{3}$ water for $24 \mathrm{~h}$. The solution was transferred into a Petri dish of $10 \mathrm{~cm}$ diameter and the solvent was let to evaporate slowly under ambient conditions. $53 \mathrm{mg}$ dry orange material could be recovered and was used in reaction within 1 year.

FT-IR measurements were recorded on a Bio-Rad Digilab Divison FTS-65 A/896 IR spectrophotometer operating in diffuse reflectance mode between $4000-400 \mathrm{~cm}^{-1}$ using $2 \mathrm{~cm}^{-1}$ resolution by averaging 256 scans. FT-far-IR (far-infrared) spectra were recorded on a Bio-Rad Digilab Divison FTS-40 vacuum IR spectrophotometer in the $500-100 \mathrm{~cm}^{-1}$ range accumulating 256 scans with $2 \mathrm{~cm}^{-1}$ resolution using the Nujol mull technique. SEM measurements were carried out on a Hitachi S-4700 Type II FE-SEM microscope with $10 \mathrm{kV}$ accelerating voltage. The samples were mounted on a conductive carbon tape and sputter coated by a thin Au/Pd layer in $\mathrm{Ar}$ atmosphere prior to measurements. For obtaining the SEM-EDX (energy dispersive X-ray) analysis of the sample Ru-CS1 a Röntec QX2 spectrometer coupled to the microscope was used.

${ }^{1} \mathrm{H}$ and ${ }^{13} \mathrm{C}$ NMR spectra of the purified products were recorded on a Bruker AVANCE DRX 400 spectrometer using $\mathrm{CDCl}_{3}$ solvent (see Supporting Information). Products were isolated by flash chromatography on silica gel $60,40-63 \mu \mathrm{m}$, using hexane isomers/ethyl acetate (EtOAc) mixtures (as indicated in the Supporting Information). The purity of the fractions was checked by thin-layer chromatography on Kieselgel-G (Merck Si 254 F) layers. Optical rotations of the products were measured using Perkin-Elmer 341 polarimeter. The ${ }^{1} \mathrm{H}$ NMR spectrum of $\mathrm{CS} 1$ in presence of the Ruprecursor or TFA following $24 \mathrm{~h}$ stirring in $\mathrm{D}_{2} \mathrm{O}$ was recorded on a Bruker Ascend 500 instrument at $500 \mathrm{MHz}$.

Gas-chromatographic analysis of the reaction products were carried out using Agilent Techn. 6890 N GC-5973 MSD (GC-MSD) equipped with 30 or $60 \mathrm{~m}$ long HP-1MS capillary columns for mass spectrometric identification of the products. For quantitative analysis Agilent 7890 A GC-FID (GC-FID) chromatograph equipped with chiral capillary column (Cyclodex-B $30 \mathrm{~m}$, J\&W; Cyclosil-B $30 \mathrm{~m}$, $\mathrm{J} \& \mathrm{~W}$ or HP-Chiral $30 \mathrm{~m}, \mathrm{~J} \& \mathrm{~W}$ from Agilent or Hydrodex g-TBDAC, $25 \mathrm{~m}$ from Macherey-Nagel) was used.

\section{Transfer Hydrogenation: General Procedure}

The reactions were carried out in $4 \mathrm{~cm}^{3}$ closed glass vials. The slurries were stirred magnetically $(800 \mathrm{rpm})$. If higher than $\mathrm{rt}$ was necessary the vials were immersed in a heated oil bath. In a typical reaction the given amounts of $\left[\mathrm{Ru}(p-c y m) \mathrm{Cl}_{2}\right]_{2}$, chitosan and $1 \mathrm{~cm}^{3}$ solvent were introduced into the vial and stirred at $\mathrm{rt} 1 \mathrm{~h}$ followed by addition of the required amount of HCOONa (typically $1.25 \mathrm{mmol}$ ) and further stirred $1 \mathrm{~h}$. Finally, the prochiral ketone $(0.25 \mathrm{mmol})$ was added to the mixture and stirred for the given time. Following the reactions, the products were extracted in $3 \mathrm{~cm}^{3}$ EtOAc, the aqueous phase was washed twice with $2 \mathrm{~cm}^{3} \mathrm{EtOAc}$, the unified organic phase was dried using $\mathrm{MgSO}_{4}$ (sicc) and analyzed by gas-chromatography (GC-MSD and GC-FID). Reactions at $1 \mathrm{mmol}$ ketone scales were carried out similarly as above in $8 \mathrm{~cm}^{3}$ vials using the amounts given in Table 3 . Reactions at gram scale (5 or $8 \mathrm{mmol}$ ) were carried out under identical conditions increasing the reaction components proportionally. Following GC analysis of the crude products the solvent was removed by evaporation and the pure products were obtained by flash chromatography. These products were analyzed by GC-MSD, GC-FID, ${ }^{1} \mathrm{H}$ and ${ }^{13} \mathrm{C}$ NMR spectroscopy and their optical rotations were measured (see Supporting Information). Products obtained at $8 \mathrm{mmol}$ scale were crystallized in hexane to obtain the optically pure alcohols.

Conversions (Conv) and enantioselectivities (as enantiomeric excess, ee) were calculated based on the relative concentrations determined from chromatograms using the formulae given in the Supporting Information. The absolute configuration of the excess enantiomers was assigned based on the optical rotation sign of the isolated products and literature data, ${ }^{[13,22]}$ or based on chromatographic analysis and comparison with samples of known configurations. 


\section{Acknowledgements}

Financial support of the Hungarian National Science Foundation through OTKA Grant K 109278 is appreciated. Ministry of Human Capacities, Hungary grant 20391-3/2018/ FEKUSTRAT is acknowledged. The authors thank to Dr. Gábor Varga, Tamás Gyulavári, Prof. Klára Hernádi and Prof. Enikö Forró for their valuable help in characterizing the materials.

\section{Conflict of Interest}

The authors declare no conflict of interest.

\section{Keywords: enantioselective · transfer hydrogenation} chitosan $\cdot$ ketones $\cdot$ ruthenium
Biotechnol. 2006, 8, 203-226; d) V. Zargar, M. Asghari, A. Dashti, ChemBioEng Rev. 2015, 2, 204-226.

[6] a) E. I. Rabea, M. E.-T. Badawy, C. V. Stevens, G. Smagghe, W. Steurbaut, Biomacromolecules 2003, 4, 1457-1465; b) E. Guibal, Sep. Purif. Technol. 2004, 38, 43-74; c) P. Miretzky, A. Fernandez Cirelli, J. Hazard. Mater 2009, 167, 10-23; d) H. Honarkar, M. Barikani, Monatsh. Chem. 2009 140, 1403-1420; e) N. Bhattarai, J. Gunn, M. Zhang, Adv. Drug Delivery Rev. 2010, 62, 83-99; f) S. K. Shukla, A. K. Mishra, O. A. Arotiba, B. B. Mamba, Int. J. Biol. Macromol. 2013, 59, 46-58; g) E. Guibal, T. Vincent, R. Navarro, J. Mater. Sci. 2014, 49, 5505-5518; h) J. Desbrières, E. Guibal, Polym. Int. 2018, 67, 7-14; i) S. M. Ahsan, M. Thomas, K. K. Reddy, S. G. Sooraparaju, A. Asthana, I. Bhatnagar, Int. J. Biol. Macromol. 2018, 110, 97-109; j) A. Baranwal, A. Kumar, A. Priyadharshini, G. S. Oggu, I. Bhatnagar, A. Srivastava, P. Chandra, Int. J. Biol. Macromol. 2018, 110, 110-123; k) I. Aranaz, N. Acosta, C. Civera, B. Elorza, J. Mingo, C. Castro, M. de los Llanos Gandía, A. H. Caballero, Polymer 2018, 10, 213.

[7] a) H. Zhang, W. Zhao, J. Zou, Y. Liu, R. Li, Y. Cui, Chirality 2009, 21, 492496; b) Y. Qin, W. Zhao, L. Yang, X. Zhang, Y. Cui, Chirality 2012, 24, 640-645; c) C. Gioia, A. Ricci, L. Bernardi, K. Bourahla, N. Tanchoux, M. Robitzer, F. Quignard, Eur. J. Org. Chem. 2013, 588-594; d) T. Heckel, D. D. Konieczna, R. Wilhelm, Catalysts 2013, 3, 914-921; e) A. El Kadib, ChemSusChem 2014, 8, 217-244; f) O. Mahé, J.-F. Brière, I. Dez, Eur. J. Org. Chem. 2015, 2559-2578; g) H. Dong, J. Liu, L. Ma, L. Ouyang, Catalysts 2016, 6, 186; h) J. M. Andrés, F. González, A. Maestro, R. Pedrosa, M. Valle, Eur. J. Org. Chem. 2017, 3658-3665.

[8] a) P. Buisson, F. Quignard, Aust. J. Chem. 2002, 55, 73-78; b) Y. Cui, L. Zhang, Y. Li, Polym. Adv. Technol. 2005, 16, 633-637; c) E. Guibal, Prog. Polym. Sci. 2005, 30, 71-109; d) E. D. Finashina, V. I. Isaeva, L. M. Kustov, N. S. Gulyukina, G. N. Bondarenko, I. P. Beletskaya, Russ. J. Org. Chem. 2006, 42, 990-995; e) J. Liu, W. Sun, S. Zheng, C. Xia, Helv. Chim. Acta 2007, 90, 1593-1598; f) T. C. O. Mac Leod, V. Palaretti, V. P. Barros, A. L. Faria, T. A. Silva, M. D. Assis, Appl. Catal. A 2009, 361, 152-159; g) S. Schüßler, N. Blaubach, A. Stolle, G. Cravotto, B. Ondruschka, Appl. Catal. A 2012, 445-446, 231-238; h) A. El Kadib, M. Bousmina, Chem. Eur. J. 2012, 18, 8264-8277; i) B. C. E. Makhubela, A. Jardine, G. S. Smith, Green Chem. 2012, 14, 338-347; j) R. B. Nasir Baig, B. R. Vaddula, M. A. Gonzalez, R. S. Varma, RSC Adv. 2014, 4, 9103-9106; k) S. Tarannum, Z. N. Siddiqui, Appl. Organomet. Chem. 2016, 30, 473-480; I) P. Xu, B. Li, L. Wang, C. Qin, L. Zhu, Catal. Commun. 2016, 86, 23-26.

[9] a) W. Sun, C.-G. Xia, H.-W. Wang, New J. Chem. 2002, 26, 755-758; b) H. Wang, W. Sun, C. Xia, J. Mol. Catal. A 2003, 206, 199-203; c) L. Xue, D.-J. Zhou, L. Tang, X.-F. Ji, M.-Y. Huang, Y.-Y. Jiang, React. Funct. Polym 2004, 58, 117-121; d) C. Shen, J. Qiao, L. Zhao, K. Zheng, J. Jin, P. Zhang, Catal. Commun. 2017, 92, 114-118.

[10] a) M.-Y. Yin, G.-L. Yuan, Y.-Q. Wu, M.-Y. Huang, Y.-Y. Jiang, J. Mol. Catal. A 1999, 147, 93-98; b) D.-Q. Zhou, M. He, Y.-H. Zhang, M.-Y. Huang, Y.-Y. Jiang, Polym. Adv. Technol. 2003, 14, 287-291; c) W.-L. Wei, S.-J. Hao, J. Zhou, M.-Y. Huang, Y.-Y. Jiang, Polym. Adv. Technol. 2004, 15, 287-290; d) D.-Q. Zhou, D.-J. Zhou, X.-H. Cui, F.-M. Wang, M.-Y. Huang, Y.-Y. Jiang, Polym. Adv. Technol. 2004, 15, 350-354.

[11] a) Y. Sun, Y. Guo, Q. Lu, X. Meng, W. Xiaohua, Y. Guo, Y. Wang, X. Liu, Z. Zhang, Catal. Lett. 2005, 100, 213-217; b) B. Liu, H. Zhou, Y. Li, J. Wang, Chinese J. Org. Chem. 2014, 34, 2554-2558.

[12] M. Babin, R. Clément, J. Gagnon, F.-G. Fontaine, New J. Chem. 2012, 36, 1548-1551.

[13] a) J. S. Yadav, S. Nanda, P. Thirupathi Reddy, A. Bhaskar Rao, J. Org Chem. 2002, 67, 3900-3903; b) Y. Xu, G. F. Docherty, G. Woodward, M Wills, Tetrahedron: Asymmetry 2006, 17, 2925-2929; c) J.-H. Xie, X.-Y. Liu, J.-B. Xie, L.-X. Wang, Q.-L. Zhou, Angew. Chem. Int. Ed. 2011, 50, 73297332; Angew. Chem. 2011, 123, 7467-7470.

[14] a) K. Kurita, H. Ikeda, Y. Yoshida, M. Shimojoh, M. Harata, Biomacromolecules 2002, 3, 1-4; b) M. Matwiejuk, J. Thiem, Eur. J. Org. Chem. 2011 5860-5878; c) M. Babin, A. Ruest, G. Drouin, K. Sirois, S. Ouellet, J. Gagnon, Carbohydr. Res. 2012, 351, 87-92.

[15] a) T. Xu, M. Xin, M. Li, H. Huang, S. Zhou, J. Liu, Carbohydr. Res. 2011, 346, 2445-2450; b) S. Mekahlia, B. Bouzid, Physics Procedia 2009, 2 1045-1053.

[16] J. Takehara, S. Hashiguchi, A. Fujii, S. Inoue, T. Ikariya, R. Noyori, Chem Commun. 1996, 233-234.

[17] a) J. Qu, Q. Hu, K. Shen, K. Zhang, Y. Li, H. Li, Q. Zhang, J. Wang, W. Quan, Carbohydr. Res. 2011, 346, 822-827; b) H. Naeimi, S. Lahouti, Appl. Organomet. Chem. 2017, 31, e3732; c) L. Gritsch, C. Lovell, W. H. Goldmann, A. R. Boccaccini, Carbohydr. Polym. 2018, 179, 370-378.

[18] a) F. Marchetti, C. Pettinari, R. Pettinari, A. Cerquetella, C. Di Nicola, A. Macchioni, D. Zuccaccia, M. Monari, F. Piccinelli, Inorg. Chem. 2008, 47, 
11593-11603; b) J. B. Cornell, Far-Infrared Studies of Metal-Ligand Vibrations, PhD Thesis, Univ. of Leicester, 1968; c) J. R. Durig, Y. Omura, E. E. Mercer, J. Mol. Struct. 1975, 29, 53-63.

[19] a) A. Hirai, H. Odani, A. Nakajima, Polym. Bull. 1991, 26, 87-94; b) M. Lavertu, Z. Xia, A. N. Serreqi, M. Berrada, A. Rodrigues, D. Wang, M. D. Buschmann, A. Gupta, J. Pharm. Biomed. Anal. 2003, 32, 1149-1158; c) C. Zhang, Q. Ping, H. Zhang, J. Shen, Carbohydr. Polym. 2003, 54, 137-141; d) S. A. Johannesen, B. O. Petersen, J. Ø. Duus, T. Skrydstrup, Inorg. Chem 2007, 46, 4326-4335; e) Y. Wang, A. Pitto-Barry, A. Habtemariam, I. Romero-Canelon, P. J. Sadler, N. P. E. Barry, Inorg. Chem. Front. 2016, 3, 1058-1064.

[20] N. V. Kramareva, A. Yu. Stakheev, O. P. Tkachenko, K. V. Klementiev, W. Grünert, E. D. Finashina, L. M. Kustov, J. Mol. Catal. A 2004, 209, 97-106.

[21] a) K.-J. Haack, S. Hashiguchi, A. Fujii, T. Ikariya, R. Noyori, Angew. Chem. Int. Ed. Engl. 1997, 36, 285-288; b) D. A. Alonso, P. Brandt, S. J. M. Nordin, P. G. Andersson, J. Am. Chem. Soc. 1999, 121, 9580-9588; c) M. Yamakawa, H. Ito, R. Noyori, J. Am. Chem. Soc. 2000, 122, 1466-1478 d) S. E. Clapham, A. Hadzovic, R. H. Morris, Coord. Chem. Rev. 2004, 248, 2201-2237; e) J. S. M. Samec, J.-E. Bäckvall, P. G. Andersson, P. Brandt,
Chem. Soc. Rev. 2006, 35, 237-248; f) J. Canivet, G. Süss-Fink, Green Chem. 2007, 9, 391-397; g) J.-W. Handgraaf, E. J. Meijer, J. Am. Chem. Soc. 2007, 129, 3099-3103; h) X. Wu, J. Liu, D. Di Tommaso, J. A. Iggo, C. R. A. Catlow, J. Bacsa, J. Xiao, Chem. Eur. J. 2008, 14, 7699-7715.

[22] a) R. P. Singh, B. Twamley, L. Fabry-Asztalos, D. S. Matteson, J. M. Shreeve, J. Org. Chem. 2000, 65, 8123-8125; b) W. He, P. Liu, B. L. Zhang X. L. Sun, S. Y. Zhang, Appl. Organomet. Chem. 2006, 20, 328-334; c) M. Braun, M. Sigloch, J. Cremer, Adv. Synth. Catal. 2007, 349, 337-342; d) S. Zeror, J. Collin, J.-C. Fiaud, L. A. Zouioueche, Adv. Synth. Catal. 2008, 350, 197-204; e) J. E. D. Martins, D. J. Morris, B. Tripathi, M. Wills, J. Organomet. Chem. 2008, 693, 3527-3532.

Manuscript received: October 1, 2018

Revised manuscript received: November 6, 2018

Accepted manuscript online: November 13, 2018

Version of record online: December 5, 2018 